\title{
Dampak Konglomerasi Media Terhadap Industri Media Massa dan Demokrasi Ekonomi Politik di Era Konvergensi Media
}

\section{The Impact of Media Conglomeration on the Mass Media Industry and Political Economy Democracy in the Era of Media Convergence}

\author{
Umi Khumairoh \\ Program Studi Ilmu Komunikasi FISIP Universitas Gajah Mada \\ Email: umikhumairoh@mail.ugm.ac.id
}

\begin{abstract}
Abstrak
Penelitian ini membahas tentang konglomerasi media di era konvergensi media. Obyek dalam penelitian ini adalah bagaimana dampak konglomerasi media terhadap demokrasi ekonomi politik di Indonesia. Selain itu, penelitian ini juga menjelaskan tentang bagaimana dampak adanya konvergensi media terhadap industri media massa saat ini. Metode penelitian ini menggunakan pendekatan deskriptif kualitatif dengan studi literatur dan pengumpulan data melalui data sekunder yang diperoleh melalui studi kepustakaan sepertu buku-buku referensi, jurnal, artikel dan sumber lainnya yang berkaitan dengan penelitian. Penelitian ini menyimpulkan bahwa konvergensi media melibatkan banyak faktor teknologi di dalamnya. Di dukung oleh kehadiran internet, maka mendukung penerapan konvergensi media yang menyatukan beberapa media seperti media online, e-paper, e-books, radio streaming, dan media sosial.
\end{abstract}

Kata kunci: konglomerasi media, demokrasi, media massa, konvergensi media 
64 | Dampak Konglomerasi Media Terhadap Industri Media Massa...

\begin{abstract}
This study discuss about conglomeration media in convergence media era. The object of this research is how the impact of conglomeration media on politic economy democracy in Indonesia. In addition, this study also explain how the impact of media convergence on the mass media industry today. This research method uses a descriptive qualitative with literature studies approach and data collection through secondary data obtained through literature studies such as reference book, journals, articles and other sources related to research. This study concludes that media convergence involves many technological factors. Supported by the presence of the internet, it supports the application of media convergence that unites several media such as online media, e-paper, e-books, radio streaming, and social media.
\end{abstract}

Keywords: media conglomeration, democracy, mass media, media convergence

\title{
Pendahuluan
}

Dewasa ini, adanya konvergensi media atau penyatuan berbagai layanan dan teknologi komunikasi serta informasi (ICTS-Information and Communication Technology and Services) seiring dengan perkembangan teknologi digital memiliki dampak positif dan negatif dalam berbagai aspek kehidupan khususnya bagi demokrasi politik di Indonesia dan kemajuan industri media massa.

Terry Flew dalam New Media: an Introduction (2008) menyatakan konvergensi media merupakan hasil dari irisan tiga unsur new media yaitu jaringan komunikasi, teknologi informasi, dan konten media. Konvergensi media menjadikan media massa saat ini semakin memiliki kekuatan untuk mempengaruhi opini masyarakat dari berbagai konten yang disajikan dalam berbagai output terutama pada jenis media yang saat ini digandrungi oleh masyarakat yaitu media sosial (facebook, instagram, website, youtube, dan lain sebagainya).

Kekuatan media massa di era konvergensi media saat ini seringkali dimanfaatkan oleh oknum tertentu untuk mempengaruhi publik atau masyarakat dalam mendapatkan atau mempertahankan kekuasaan. Oleh karenanya, konvergensi media ini memiliki kaitan yang sangat erat dengan demokrasi. Saat ini masyarakat digiring oleh media dengan berbagai programnya yang mengarah pada dukungan terhadap ideologi pemilik media tersebut.

Media saat ini dapat dijadikan alat propaganda bahkan media dapat juga dimanipulasi untuk kekuasaan bahkan kepentingan bisnis pemilik media. Dengan adanya dugaan media bisa dimanipulasi, maka tidak menutup kemungkinan bahwa media dapat mematikan ruang demokrasi di tanah air ini. Penerapan demokrasipun tidak sepenuhnya dilakukan oleh media massa sehingga peran media massa untuk menyalurkan pendapat ataupun pikiran rakyat kian menghilang.

Seharusnya, media memberikan ruang bagi publik untuk berinteraksi dengan leluasa menggunakan kebebasannya dalam berpendapat. Namun, justru saat ini 
meskipun negara Indonesia merupakan negara demokrasi, Pemerintah maupun oknum tertentu seringkali mengintervensi media untuk tidak pro rakyat.

Louis Althusser (2008) berpendapat bahwa media, dalam hubungannya dengan kekuasaan menempati posisi strategis terutama karena anggapan akan kemampuannya sebagai sarana legitimasi. Media merupakan alat kekuasaan negara yang bekerja secara ideologis membangun kepatuhan khalayak terhadap kelompok yang berkuasa.

Pendapat Althusser tersebut cukup menggambarkan betapa besarnya kekuatan media di era konvergensi ini untuk mempengaruhi publik atau masyarakat di bidang politik atau mempertahankan kekuasaan. Selain itu, dengan adanya konvergensi media ini, maka tidak terlepas dari perkembangan media itu sendiri. Dulu media massa masih berupa media cetak dan radio, namun saat ini semakin berkembang menjadi media elektronik lainnya seperti televisi dan bahkan sudah dilengkapi dengan jaringan internet. Masyarakat pun dapat dengan mudah mengakses informasi tanpa batas ruang dan waktu.

Mengakses informasi melalui berbagai platform yang menggunakan internet dinilai lebih efisien dibanding dengan bentuk media lain. Internet memberikan layanan yang cepat, lengkap (audio dan visual), murah, serta beragam. Bagi media yang tidak mampu beradaptasi dengan adanya konvergensi media ini, maka lambat laun akan memasuki jurang kebangkrutan.

Selain menjadi alat mempertahankan kekuasaan dan penyebaran informasi, media massa saat ini juga menjadi ladang bisnis yang menjanjikan. Konglomerasi media merupakan salah satu akibat dari pemanfaatan media massa tersebut. Berbagai media massa berlomba-lomba untuk menciptakan program yang unik dan menarik agar dapat dipilih oleh masyarakat. Sebagai contoh, media yang bergerak dalam bentuk internet, bersaing untuk menemukan strategi clik bait yang paling menguntungkan. Untuk mendapatkan rupiah dari setiap clik, seringkali media massa memunculkan konten-konten menarik yang terkadang sebenarnya tidak penting.

Ada juga yang memberikan konten-konten campuran dalam penyajiannya seperti sebuah pemberitaan yang terdapat bentuk audio dan visual yang akan membantu audiens dalam memahami dan 'menikmati' pemberitaan tersebut. Konvergensi media ini menjadi kondisi yang tidak dapat dihindari oleh industri media, karena semakin menghindarinya, justru akan semakin terpuruk.

Dalam menjalani konvergensi media ini, industri media harus memiliki berbagai media untuk dapat menjalankan bentuk multiplatform (Epkamarsa 2014). Cara ini dinilai efektif karena dapat memberikan kekuatan dan keuntungan media tersebut di mana setiap kekurangan yang ada akan ditutupi oleh bentuk media yang lainnya. Informasi yang didapatkan juga semakin lengkap karena berasal dari berbagai sumber media dan dapat menjangkau lebih banyak kalangan. Masyarakat yang tidak memiliki televisi, bisa mendapatkan informasi dalam bentuk radio, cetak dan internet.

Konvergensi media tidak hanya dilakukan oleh satu bentuk ke bentuk media yang lain, misalnya cetak terhadap internet, namun juga bisa dilakukan dalam 
66 | Dampak Konglomerasi Media Terhadap Industri Media Massa...

bentuk media yang sama sehingga tidak menghambat konglomerasi media. Hal yang paling penting dalam konglomerasi media ini yaitu mendapatkan keuntungan sebesar-besarnya.

Pemilik modal kecil dapat diakuisisi oleh media yang lebih besar sehingga konglemerasi media ini membuat media tersebut menjadi media raksasa yang mendapatkan tempat di berbagai kalangan masyarakat. Pada akhirnya, uanglah yang menjadi tujuan konvergensi media.

Dalam artikelini penulis mengangkat penelitian terdahulu yang dapat menjadi dasar penguat untuk dilakukannya penelitian terkait dampak konglomerasi media terhadap industri media massa dan demokrasi ekonomi politik di era konvergensi media.

\section{Tinjauan Pustaka}

Penelitian pertama dilakukan oleh Anton Wahyu Prihartono (2016) yang membahas tentang surat kabar dan konvergensi media. Penelitian ini menunjukkan bahwa konvergensi media merupakan pilihan yang harus diambil oleh media baik media cetak maupun televisi. Media massa harus mampu menyesuaikan dengan perkembangan zaman khususnya di tengah persaingan industri media yang semakin kompetitif jika tidak maka akan ditinggalkan oleh audiens. Dalam hal ini, platform cetak di Solopos tetap dipertahankan dan terus ditingkatkan oplah dan pendapatan iklannya. Sementara online juga harus dipersiapkan sejak dini dan sebisa mungkin mendatangkan penghasilan. Selanjutnya pengelolaannya dikombinasikan oleh masing-masing platform tersebut. Reporter dituntut untuk mengubah cara kerjanya. Seorang reporter tidak hanya bekerja untuk satu media yakni Solopos, tetapi juga untuk Solopos.com, Solopos.tv dan juga radio.

Penelitian kedua dilakukan oleh Dian Muhtadiah Hamna (2018) yang membahas tentang konvergensi media terhadap kinerja jurnalis. Penelitian ini menunjukkan bahwa adanya konvergensi media memengaruhi jurnalis yang bekerja ganda untuk memenuhi kebutuhan perusahaan media. Konvergensi ini juga menyebabkan jurnalis mau tidak mau dituntut meningkatkan skill memenuhi kebutuhan Sumber Daya Manusia (SDM) platform media. Selain itu, diketahui bahwa konvergensi media belum memengaruhi tingkat kesejahteraan jurnalis. Meski berperan ganda, jurnalis Fajar TV dan Fajar FM masih menerima upah untuk satu platform media.

Penelitian ketiga dilakukan oleh Karman (2014) yang membahas tentang monopolikepemilikan media danlenyapnyahakpublik. Penelitianinimenunjukkan adanya kecenderungan media untuk membela dan memperjuangkan kepentingan pribadi sementara hak publik terabaikan. Hak masyarakat untuk mendapatkan informasi yang beragam menjadi hilang dan terampas. Harus diakui bahwa media berada pada tiga pusaran yang melingkupi media itu sendiri, yaitu: negara (politik, termasuk pemilihan umum), pasar (para pengiklan, konsumen, pemodal), dan publik. Jadi, isi media -bila dikaji dari ekonomi politiknya- ditentukan oleh kekuatan-kekuatan politik, ekonomi pemilik dan pendapatan media itu sendiri. 


\section{Metodologi}

\section{Jenis Penelitian}

Jenis penelitian yang digunakan adalah pendekatan kualitatif, yaitu penelitian yang digunakan untuk meneliti pada kondisi obyek alamiah, peneliti adalah sebagai instrumen kunci, teknik pengumpulan data dilakukan secara kualitatif, analisis data bersifat induktif/kualitatif, dan hasil penelitian kualitatif lebih menekankan makna daripada generalisasi. Jenis penelitian termasuk dalam penelitian eksploratif yaitu dilakukan untuk mengetahui dan menjelaskan permasalahan yang awalnya peneliti hanya memahami permasalahan yang ada secara umum, baru kemudian peneliti melakukan penelitian. Penelitian eksploratif memiliki masalah yang belum pernah dijejaki, dan berusaha menemukan atau mengungkap permasalahan yang sedang dibutuhkan atau akan diteliti tersebut. Metode penelitian menggunakan studi literatur yaitu peneliti menelaah secara tekun akan kepustakaan yang diperlukan dalam penelitian dan juga mengkombinasikan dengan menggunakan wawancara pada informan yang diperlukan dalam penelitian.

\section{Obyek Penelitian}

Obyek penelitian adalah sasaran ilmiah untuk mendapatkan data dengan tujuan dan kegunaan tertentu tentang suatu hal objektif, valid, dan reliable tentang suatu hal atau variabel tertentu. Obyek dalam penelitian ini adalah bagaimana dampak konglomerasi media terhadap demokrasi dan industri media massa di era konvergensi media.

\section{Jenis dan Sumber Data}

Penelitian ini menggunakan studi literatur selain dari mencari sumber data sekunder yang akan mendukung penelitian, juga diperlukan untuk mengetahui sampai ke mana ilmu yang berhubungan dengan penelitian telah berkembang, sampai ke mana terdapat kesimpulan dan generalisasi yang telah pernah dibuat, sehingga situasi yang diperlukan dapat diperoleh. Penelitian kualitatif ini menggunakan sumber data sekunder. Data sekunder, yaitu data yang tidak langsung memberikan data kepada peneliti atau data yang telah dikumpulkan oleh lembaga pengumpulan data dan dipublikasikan kepada masyarakat pengguna data. Data sekunder dalam penelitian ini diperoleh dari referensi yang diperoleh melalui studi kepustakaan, seperti buku-buku referensi, jurnal, artikel, dan sumber lainnya yang relevan dengan penelitian.

\section{Analisis Data}

Analisa data dilakukan dengan studi literatur dan wawancara. Studi literatur dilakukan dengan membaca sumber-sumber kepustakaan untuk memperoleh data yang diperlukan dengan langkah-langkah, seperti membaca segala keterangan yang ada dalam penelitian apakah tersedia keterangan-keterangan sesuai dengan latar belakang permasalahan penelitian. Kemudian mengumpulkan sumber bahan kajian yang relevan dengan masalah dalam penelitian. Selanjutnya mengutip informasi yang ada pada bacaan, dapat berupa kuotasi (mengutip secara langsung), paraphrase (menggunakan kata-kata sendiri) dan menuliskan hasil kajian ke 
dalam kartu yang telah disediakan. Selain itu juga, mencatat hal-hal penting dengan melihat dahulu mana yang penting dengan juga mempelajari indeks di halaman belakang buku untuk mencari halaman yang berkenaan dengan yang dicatat dalam kartu yang disediakan. Yang terakhir menyimpulkan hasil yang diperoleh, dan melakukan interpretasi atas hasil yang diperoleh.

\section{Temuan dan Analisis}

\section{Konglomerasi Media dan Demokrasi Politik}

Konglomerasi adalah sekumpulan pelaku konglomerat yang menanamkan sahamnya pada perusahaan dalam satu koordinasi sehingga seluruh kebijakan manajemen yang pokok ditentukan oleh satu pintu. Konglomerasi ini merupakan satu kesatuan yang sangat besar kekuatannya, sehingga bisa mengatur harga transaksi antar perusahaan (untuk menghindari pajak), mudah mengalahkan pesaingnya, bisa mengadakan subsidi silang sehingga harganya selalu bisa bersaing, bisa mengatur harga transaksi antar perusahaan (untuk menghindari pajak), dan mempunyai bargaining power.

Pada dasarnya praktik konglomerasi media adalah ketika perusahaan media saling bergabung menjadi perusahaan yang lebih besar yang membawahi banyak media termasuk jenis-jenis media yang beragam sebagai bagian dari bisnisnya. Hal ini bisa dilakukan dengan cara membeli saham, joint venture/merger, atau akuisisi (mengambil alih).

Adanya konglomerasi media ini mengarah pada persaingan bisnis tidak sehat antar pemilik media massa sehingga menyebabkan beberapa perubahan terutama dalam membuat konten siaran atau pemberitaan pers yang menjadi subjektif dan sarat kepentingan. Hal ini berkaitan dengan keuntungan yang diperoleh oleh pemilik media massa yaitu memiliki popularitas melalui konten yang dibuat oleh jurnalisnya. Dan ini tentunya sangat bertolak belakang dengan prinsip media yang harus menjadi lembaga yang independen, objektif, jujur dan netral. Tidak adanya keberagaman isi siaran (diversity of content) dan keberagaman kepemilikan (diversity of ownership) akan membuat penyeragaman opini publik. Penyeragaman opini dan kekuatan bisnis politik oleh kekuatan media yang dominan akan mengancam kebebasan pers dan demokratisasi media. Sedangkan sebuah negara dikatakan demokrasi apabila Pemerintah memberikan kebebasan kepada rakyatnya untuk menyampaikan pendapat atau opini baik secara lisan maupun tulisan.

Media saat ini belum sepenuhnya dapat digunakan untuk mencapai sebuah demokrasi. Masyarakat memiliki ekspektasi yang tinggi terhadap media, mereka berharap media mampu menerapkan demokrasi. Lippmann mengatakan bahwa,

"Penciptaan kesadaran bukanlah seni baru. Ini merupakan hal yang lama; yang semestinya sudah mati seiring dengan munculnya demokrasi. Namun, itu tidak punah, bahkan pada kenyataannya hal tersebut telah mengalami kemajuan secara teknis, karena penciptaan kesadaran saat ini didasarkan pada analisis bukan sekadar pada aturan semata. Maka dari itu, sebagai akibat dari riset psikologis dan didukung oleh cara-cara komunikasi modern, praktek komunikasi berubah dengan cukup drastis. Sebuah revolusi telah terjadi....." 
Maksud dari pernyataan tersebut yaitu Lippmann menganggap bahwa pendapat publik sebenarnya ditentukan oleh pemberitaan media, yang tentunya disertai dengan berbagai propaganda industri media massa. Selain itu, industri media massa memiliki masing-masing populasi yang terdiri dari media-media yang secara tidak langsung membentuk suatu kelompok yang hidup dari sumber daya yang sama, misalnya populasi radio, populasi surat kabar, atau populasi televisi.

Symthe membagi tiga hal yang bisa digunakan sebagai patokan untuk mengidentifikasi karakteristik suatu ind ustri media. Pertama, customer requirements, merujuk kepada harapan konsumen tentang produk yang mencakup diversitas, kualitas dan ketersediaan. Kedua, competitive environment, lingkungan pesaing yang dihadapi oleh perusahaan. Ketiga, social expectation, berhubungan dengan tingkat harapan masyarakat terhadap keberadaan industry.

Beberapa faktor yang menjadi sumber terjadinya konsentrasi industri, adalah kemajuan teknologi. Kemajuan teknologi pada satu sisi berguna untuk meningkatkan, efisiensi, tetapi di sisi lain menyebabkan sebagian pengusaha dapat menguasainya untuk mencapai kinerja yang efisien sehingga muncul akumulasi modal dan kekayaan di tangan beberapa orang atau kelompok. Selain itu adalah merger. Merger akan menyebabkan peningkatan kekuatan pasar yang berpotensi mengurangi persaingan sehingga merger harus dibatasi. Pembatasan merger biasanya didasarkan pada ukuran konsentrasi (kekuatan pasar yang besar akan menyebabkan perusahaan tersebut dalam posisi dominan).

Merujuk pada media massa sebagai instutusi pers dan institusi bisnis, maka beberapa faktor yang menyebabkan industri media berkembang yaitu (Maryani 2011):

\section{Investasi/ Modal}

Industri media tidak bisa tidak, harus memiliki modal dan kekuatan dana yang besar. Tidak mungkin sebuah media hidup hanya dengan kekuatan idealisme atau kemampuan semata. Media harus hidup dari dukungan dana untuk memudahkan pengelolaan media dan menjaga agar para pekerja yang terlibat dalam institusi media, bisa bertahan hidup dari hasil keuntungan media tersebut.

2. Sumber Daya Manusia (SDM)

Pekerja media merupakan kekuatan terbesar dalam sebuah institusi media massa. Meski modal, teknologi, dan lainnya tersedia; namun jika tanpa SDM, maka media massa tak akan mampu berjalan.

3. Perkembangan Teknologi

Teknologi disadari sebagai alat kemajuan ketika memberikan kontribusi konkret atas masyarakat. Persebaran inovasi bias dimulai dari tingkat pengetahuan atau ide baru dari media, ada proses penyerapan teknologi dari masyarakat, selanjutnya masyarakat menyaring teknologi dan inovasi yang dirasa bermanfaat untuk mereka. Saat ini, perkembangan media massa modern tidak terelakkan. Perkembangan teknologi komunikasi ini harus 
diikuti dengan pemahaman yang layak atas pengguna teknologi itu sendiri.

4. Media sebagai entitas ekonomi

Dalam ranah bisnis, media sama halnya dengan perusahaan lainnya yang juga harus berorientasi pada profit. Namun, perbedaan institusi media massa dengan media lainnya adalah, produk yang dihasilkan bisnis media massa adalah produk yang mempengaruhi pemikiran, cara pandang, sikap dan perilaku khalayak terhadap lingkungan. Karenanya diperlukan talent industri di mana pekerja media memiliki keahlian dalam mengolah dan mengemas informasi yang akan sangat berpengaruh pada kualitas produk. Dalam produk tersebut, harus ada kompromi antara idealism, komersialisme dalam balutan profesionalisme.

5. Regulasi Media

Regulasi media dalam skala kebijakan, juga sangat menentukan iklim pertumbuhan media massa. Undang-undang yang mengakomodir kepentingan masyarakat, institusi media, dunia usaha dan juga pemerintah, adalah gambaran ideal dalam suatu aturan regulasi. Namun, tentu tidak semua kepentingan tersebut akan terakomodir secara dominan.

Dengan demikian, dapat dipahami bahwa media massa saat ini di era konvergensi media memiliki peluang yang sangat besar untuk berkembang karena kemajuan teknologi. Selain itu, berkembangnya media juga memberikan kesempatan kepada sumber daya manusia yang memiliki kompetensi di bidang media untuk berkiprah memajukan media massa saat ini agar dapat bersaing dengan media lokal, nasional bahkan media internasional lainnya. Dan hal yang terpenting saat ini yaitu kepemilikan modal yang menjadi sumber kemajuan sebuah media karena banyak sekali media massa terutama media cetak yang tidak dapat bersaing di dunia global karena terhambat oleh modal.

\section{Konvergensi Media}

Konvergensi media merupakan salah satu perkembangan teknologi digital termasuk di dalamnya yaitu media massa yang melibatkan banyak faktor teknologi di dalamnya seperti integrasi teks, angka, gambar, video, dan suara. Kehadiran internet mendorong media massa menerapkan konsep konvergensi media seperti media online, e-paper, e-books, radio streaming, media sosial, yang digabungkan dengan media lainnya.

Terry Flew (2008) menyatakan konvergensi media merupakan hasil dari irisan tiga unsur new media yaitu jaringan komunikasi, teknologi informasi, dan konten media. Konvergensi media mengubah industri, layanan dan praktik kerja yang sudah mapan dan memungkinkan munculnya bentuk-bentuk konten baru sepenuhnya.

Jenkins menjelaskan bahwa konvergensi media terintegrasi ke konvergensi budaya, sebagai interaksi antara media baru dan tradisional. Dia menganggap tidak hanya perubahan teknologi dalam konvergensi, tetapi juga dampaknya pada industri media dan audiensnya. 
Dengan demikian, dapat dipahami bahwa kunci dari konvergensi media adalah digitalisasi, karena seluruh bentuk informasi maupun data diubah dari format analog ke format digital sehingga dikirim ke dalam satuan bit (binary digital). Konvergensi media melibatkan interkoneksi teknologi informasi dan komunikasi, jaringan computer dan konten media. Hal ini menyatukan "tiga C"Computing, Communication dan Content- merupakan konsekuensi langsung dari digitalisasi konten media dan mempopulerkan internet.

Murdock menyebutkan bahwa konvergensi media ditentukan oleh evolusi digital yang terdapat pada tiga tingkatan tingkat teknologi (sistem komunikasi), tingkat konten dan tingkat ekonomi (terkait dengan perusahaan, pengusaha dan pasar media).

Berikut ini beberapa dampak positif dan negatif yang disebabkan oleh konvergensi media :

1. Dampak Positif Konvergensi Media

a. Munculnya berbagai sumber belajar seperti perpustakaan online, diskusi online dan lainnya.

b. Inovasi akan semakin berkembang di berbagai bidang.

c. Media massa berbasis digital bermunculan dan memberikan kemudahan masyakarakat dalam memperoleh informasi.

d. Informasi yang diinginkan bisa diperoleh dengan cepat.

e. Toko-toko online bermunculan sehingga memudahkan masyarakat dalam berbelanja.

2. Dampak Negatif Konvergensi Media

a. Banyak informasi tidak benar alias hoax bermunculan di media.

b. Penyalahgunaan informasi pribadi sehingga dapat mengganggu kehidupan masyarakat.

c. Menyebabkan kurangnya konsentrasi.

d. Menyebabkan kurangnya sosialisasi dengan masyarakat lainnya.

\section{Konglomerasi Media dan Demokrasi Ekonomi Politik}

Praktik konglomerasi media merupakan fenomena beberapa perusahaan yang membawahi banyak media sehingga menjadi media raksasa yang memiliki power sebagai bagian dari bisnisnya. Praktik ini dapat terjadi dengan adanya pembelian saham, merger dan akuisisi.

Dalam perkembangannya, konglomerasi media tidak hanya bersifat horizontal (mono-media-concentrations - hanya satu bentuk saja, misalnya media cetak) tapi sudah bersifat diagonal (cross media concentration - lebih dari satu bentuk media, misalnya: elektronik, cetak dan media online). Saat ini banyak media di Indonesia yang sudah melakukan konglomerasi media untuk menguasai pasar seperti MNC Group yang merupakan gabungan dari MNC TV, RCTI, Global TV, iNews di bidang televisi. Sedangkan di bidang online terdapat Sindonews. com, Okezone.com dan iNews. Sementara di luar negeri ada Murdoch's News Corp yang membeli MySpace.

Hal tersebut mengindikasikan bahwa para pengusaha sudah lebih dahulu 
sadar bahwa untuk mencapai banyak kepentingan di era konvergensi media ini, secara objektif, jenis konglomerasi media diagonal akan sangat menguntungkan pihaknya di luar kepentingan media relation. Mereka saling bersaing dengan membuat konten yang menarik dan beragam serta terus melebarkan sayapnya untuk memperkuat diri.

Organisasi tidak perlu mengejar jumlah media yang menjadi partner kerja sama, tapi cukup dengan menjalin hubungan dengan satu atau dua kelompok usaha media berjenis diagonal untuk menjangkau publik yang berbeda baik secara psikografis, demografis maupun geografis. Jangkauan publik dengan usaha minimal akan diperluas oleh sebaran publikasi dengan variasi media yang lebih beragam.

Secara umum, ekspansi dan konglomerasi media yang dilakukan oleh media, memiliki dua tendensi kepentingan berkaitan dengan kebijakan. Pertama, potensi implikasi sosial politik dan budaya yang diinginkan dari perusahaan media. Kedua, berkaitan dengan potensi ekonomi yang ingin diraih dari pengembangan usaha media tersebut. Pluralisme media berkaitan dengan implikasi sosial politik dan budaya, ketika keanekaragaman media dengan perbedaan suara yang independen mengacu pada opini politik yang merepresentasikan budaya dalam media. Terlepas dari tendensi ekonomi, masyarakat luas tentu berharap adanya keberagaman dan pluralisme baik dalam konten maupun sumber media.

Secara ideal, masyarakat juga berharap adanya keberagaman dalam kepemilikan yang kemungkinan besar akan berimplikasi pada perbedaan kebijakan dalam mengelola organisasi media. Sedangkan orientasi ekonomi lebih mengacu pada dominasi keuntungan dan dominasi pasar. Konglomerasi media dalam hal ini cenderung untuk membentuk kelompok usaha dengan konsentrasi sumber daya manusia secara efisien dalam media yang beragam.

Konglomerasi media memungkinkan adanya power di bidang politik, dan keuntungan yang besar di bidang ekonomi. Sebagian besar pemilik grup media di Indonesia berkecimpung ke kancah perpolitikan.

Ketika para pengusaha akan melakukan publikasi bisnis dengan media yang dimiliki sendiri dibanding dengan penggunaan media di luar jaringan bisnis, media dalam satu jaringan kelompok usaha menunjuk pada kepentingan akses media yang lebih mudah dan lebih efisien. Efisiensi juga mencakup penggunaan sumber daya manusia terutama untuk konglomerasi secara diagonal ketika antarmedia bisa saling bertukar materi informasi ataupun memanfaatkan SDM.

Menurut Vincent Moscow dalam bukunya The Political Economy of Communication (1998), pendekatan dengan teori ini intinya adalah ekonomi politik sebagai studi mengenai relasi sosial, khususnya relasi kekuasaan, seperti produksi, distribusi dan konsumsi sumber daya. Seperti teori Marxisme Klasik, teori ini menganggap kepemilikan media yang ada pada segelintir elit pengusaha menyebabkan penyakit sosial. Perhatian ekonomi politik diarahkan pada kontrol, kepemilikan serta kekuatan operasional pasar media.

Karakter utama pendekatan ekonomi politik adalah produksi media yang ditentukan oleh pertukaran nilai isi media yang berbagai macam di bawah kondisi 
tekanan ekspansi pasar dan juga ditentukan oleh kepentingan ekonomi-politik pemilik modal dan pembuat kebijakan media. Berbagai kepentingan tersebut berkaitan dengan kebutuhan untuk memperoleh keuntungan, sebagai akibat dari kecenderungan monopolistis dan proses integrasi, baik secara vertikal maupun spasialisasi terkait dengan bentuk lembaga media, apakah berbentuk korporasi dengan skala besar atau sebaliknya, berjaringan atau tidak, bersifat monopoli atau oligopoli, atau konglomerasi.

Penggabungan dan aliansi antar media (integrasi horisontal dan vertikal) telah menciptakan timbulnya monopoli pada suatu tatanan baru, suatu kesatuan besar konglomerat yang menyimpan potensi untuk mengendalikan produksi dan arus komunikasi, informasi serta hiburan. Kajian ekonomi politik menempatkan media sebagai instrumen dominasi yang dapat digunakan oleh pemilik modal atau horizontal.

Media sebagai agen mobilisasi, di mana media berfungsi sebagai sarana untuk meningkatkan keterlibatan warga dalam proses-proses politik yang berlangsung. Akibat adanya konglomerasi media ditambah dengan terlibatnya para pemilik media dalam aktivitas politik, mengakibatkan adanya praktik pemberitaan yang cenderung didominasi oleh personalisasi kepentingan pemilik media. Di mana personalisasi ini berkaitan dengan pembentukan konten (isi) tayangan atau berita dalam media tertentu.

Seringkali publik disodorkan dengan informasi-informasi yang berupa infotainmen, musik, atau hiburan semata. Dalam hal ini media belum mampu mendorong warga negara belajar tentang politik dan permasalahan publik bersama sehingga warga negara masih belum bisa menentukan pilihan-pilihan politik dengan cerdas. Dengan kata lain, konglomerasi media telah mengancam hak warga negara untuk berpartisipasi dalam media dan telah menyingkirkan warga negara dari peran mereka sebagai pengendali media. Padahal, dalam wacana demokrasi, sangat penting mengenai civic education atau pendidikan politik warga negara dan posisi media sangat krusial dalam pencapaian tujuan ini.

\section{Konvergensi Media dan Implikasinya pada Industri Media Massa}

Konvergensi media merupakan salah satu perkembangan media massa yang melibatkan banyak faktor teknologi di dalamnya. Kehadiran internet mendorong media massa menerapkan konsep konvergensi media seperti media online, e-paper, e-books, radio streaming, media sosial, yang digabungkan dengan media lainnya. Media yang awalnya dibatasi jenisnya, kini menyatu dan memudahkan masyarakat dalam mengakses informasi.

Terry Flew (2008) menyatakan konvergensi media merupakan hasil dari irisan tiga unsur new media yaitu jaringan komunikasi, teknologi informasi, dan konten media. Konvergensi media mengusung pada konsep penyatuan berbagai layanan informasi dalam satu piranti informasi membuat satu gebrakan digitalisasi yang tidak bisa dibendung lagi arus informasinya. Konvergensi menyebabkan perubahan radikal dalam penanganan, penyediaan, distribusi dan pemrosesan seluruh bentuk informasi baik visual, audio, data dan sebagainya (Preston 2001). 
Menurut Grant dan Wilkinson, konvergensi secara relevan dapat dibagi menjadi 5 dimensi sebagai berikut:

1. Dimensi Teknologi (yakni sebagai campuran dari industri media, telekomunikasi dan komputer, yang kemudian menyatu dan tampil bersama secara digital),

2. Dimensi konten Multiple-Media (yakni kemampuan untuk menampilkan berbagai macam format konten media hanya melalui satu media saja),

3. Dimensi kepemilikan (yakni kepemilikan dari dua media atau lebih yang melayani pasar yang sama dengan entitas tunggal),

4. Dimensi kolaborasi (yakni kolaborasi media dengan media yang sebelumnya kompetitornya), dan terakhir

5. Dimensikoordinasi (yakni keterlibatanmedia-media dalam praktikjurnalisme yang terkonvergensi meliputi berbagi berita, personil, dan sumber).

Dalam konvergensi jurnalistik dikenal adanya tiga model menurut Grant:

1. Konvergensi newsroom.

Dalam konvergensi ini jurnalis yang berbeda platform, misalnya dari surat kabar, online, dan televisi menyatukan dirinya dalam satu ruang produksi berita. Mereka mengerjakan tugas sesuai dengan platform medianya.

2. Konvergensi newsgathering.

Dalam menjalankan model ini, seorang jurnalis dituntut untuk mampu mencapai tingkatan multitasking. Dengan melalui pelatihan atau training khusus, seorang jurnalis dituntut untuk dapat melakukan pekerjaan yang dilakukan oleh media dengan platform lain dalam satu grup. Misalnya, seorang wartawan cetak harus mampu membuat berita untuk cetak, online, dan sekaligus untuk televisi. Selain itu juga dituntut untuk mengambil foto atau video.

3. Konvergensi konten.

Berita akhirnya disuguhkan dalam bentuk multimedia, yang merupakan kombinasi antara teks, gambar, audio, video, blog, podcasts, atau slide show. Pilihannya terus berkembang. Saat ini, konvergensi isi masih sangat muda atau baru dimulai. Namun, kita dapat mengintip masa depan melalui website yang inovatif. Bayangkan beberapa tahun ke depan medium hybrid baru mengkombinasikan antara audio dan video $\mathrm{tv}$, sifat responsif dan sumber dari website, kemudahan dibawa dan kualitas cetak dari koran. Editor dan reporter akan menjadi content producer yang dilatih untuk memilih cerita mana yang paling efektif, teknik yang paling menghibur dari menu biasa hingga pilihan multimedia.

Di era konvergensi media ini, jurnalis diharapkan lebih meningkatkan kualitas tulisan atau konten yang dibuatnya dan tidak hanya fokus pada keuntungan semata. Media cetak biasanya memberikan informasi yang lebih selektif dan kontennya juga terbatas. Maka dari itu, diharapkan agar jurnalis di media cetak memilih konten berita yang memiliki kualitas bagus dan mengandung informasi 
yang bermanfaat.

Saat ini, jurnalis atau content creator dituntut untuk membuat konten yang kreatif dengan mengkolaborasikan berbagai jenis tampilan informasi yang beragam sehingga memiliki kualitas yang baik. Selain itu, dalam menulis konten, jurnalis harus memperhatikan kode etik jurnalistik sehingga menjamin hak publik dalam mendapatkan informasi yang akurat dan terjamin kebenarannya.

Mengenai ini, Aris Munandar memberikan beberapa contoh tahapan yang telah dilakukan oleh jurnalisme di era digitalisasi sehingga mengarah ke bentuk konvergensi media yaitu sebagai berikut:

1. Aksi Stand-Up yang dilakukan jurnalis media cetak bertujuan untuk menghadirkan beberapa aspek dari berita di depan kamera bagi perusahaan televisi yang menjadi mitra perusahaan media cetaknya.

2. Galeri atau pertunjukkan foto-foto yang dilakukan oleh jurnalis media cetak untuk situs web dari perusahaan surat kabarnya termasuk foto-foto yang tidak memiliki ruang untuk dimuat di media cetak.

3. Berita singkat atau rangkuman, yang ditulis oleh reporter media cetak, media siaran dan media online yang kemudian digunakan untuk berita lewat e-mail atau SMS.

4. Newsroom multimedia yang terintegrasi secara penuh, dimana jurnalis bersama-sama mengumpulkan informasi, menggali data dan merencanakan paket berita yang ditujukan bagi distribusi di seluruh lintas media.

Saat ini akses di media massa online lebih mudah dan cepat sehingga banyak orang yang memilih media massa online dibandingkan konvensional. Hal ini menyebabkan pebisnis di media massa cetak juga membuka bisnis di media massa online agar dapat bertahan di industri media massa. Misalnya koran kompas yang kini juga memiliki platform berita online yang dapat diakses melalui halaman kompas.com.

Serikat Perusahaan Pers (SPP) menyebutkan bahwa jumlah penerbitan media cetak pada tahun 2017 mengalami penurunan. Dalam riset lainnya terhadap beberapa media, diketahui bahwa media radio mengalami penurunan sebesar 3,4\%; media televisi 4,2\%; media majalah 6,0\% dan media massa surat kabar mengalami penurunan sebesar $8,3 \%$.

Berdasarkan hasil riset tersebut, terlihat dengan jelas bahwa bisnis media yang paling banyak mengalami penurunan adalah media massa surat kabar. Untuk mengatasi permasalahan ini, tentunya pelaku bisnis atau pemilik media massa diharapkan lebih memperhatikan konten dan dapat merambah ke bisnis media online agar dapat bertahan dengan keadaan saat ini.

\section{Penutup}

Konvergensi media melibatkan banyak faktor teknologi di dalamnya. Di dukung oleh kehadiran internet, maka mendukung penerapan konvergensi media yang menyatukan beberapa media seperti media online, e-paper, e-books, radio streaming, media sosial. Media yang awalnya dibatasi jenisnya, kini menyatu dan 
memudahkan masyarakat dalam mengakses informasi.

Saat ini, jurnalis atau content creator dituntut untuk membuat konten yang kreatif dengan mengkolaborasikan berbagai jenis tampilan informasi yang beragam sehingga memiliki kualitas yang baik. Selain itu, dalam menulis konten, jurnalis harus memperhatikan kode etik jurnalistik sehingga menjamin hak publik dalam mendapatkan informasi yang akurat dan terjamin kebenarannya.

Namun, adanya konvergensi media tersebut, mendorong terjadinya konglomerasi media. Praktik konglomerasi media merupakan fenomena beberapa perusahaan yang membawahi banyak media sehingga menjadi media raksasa yang memiliki power sebagai bagian dari bisnisnya. Praktik ini dapat terjadi dengan adanya pembelian saham, merger dan akuisisi.

Secara umum, ekspansi dan konglomerasi media yang dilakukan oleh media, memiliki dua tendensi kepentingan berkaitan dengan kebijakan. Pertama, potensi implikasi sosial politik dan budaya yang diinginkan dari perusahaan media. Kedua, berkaitan dengan potensi ekonomi yang ingin diraih dari pengembangan usaha media tersebut.

Dengan demikian, dapat dipahami bahwa konglomerasi media ini mengarah pada persaingan bisnis tidak sehat antar pemilik media massa sehingga menyebabkan beberapa perubahan terutama dalam membuat konten siaran atau pemberitaan pers yang menjadi subjektif dan sarat kepentingan.

Tidak adanya keberagaman isi siaran (diversity of content) dan keberagaman kepemilikan (diversity of ownership) akan membuat penyeragaman opini publik. Penyeragaman opini dan kekuatan bisnis politik oleh kekuatan media yang dominan akan mengancam kebebasan pers dan demokratisasi media. 


\section{Daftar Pustaka}

Althusser, Louis. 2008. Marxis Strukturalis, Psikoanalisis, Cultural Studies. Bandung: Jalasutra.

Epkamarsa, Hutama. 2014. Perkembangan Konvergensi Media di Indonesia. Naskah Ringkas Makalah Non-Seminar. Depok: Departeman Komunikasi fakultas Ilmu Sosial dan Ilmu Politik Universitas Indonesia.

Fahrudin, D. 2013. Konglomerasi Media: Studi Ekonomi Politik terhadap Media Group. Jurnal Visi Komunikasi 12(1): 82-97. http://dx.doi.org/10.22441/jvk. v12i1.372

Flew, Terry. 2008. New Media: an Introduction. Oxford: Oxford University Press.

Gilang Pembayun, J. 2015. Konglomerasi Media dan Dampaknya pada Pilplres 2014. Jurnal Interaksi 4(2): 109 -116.

H. Assegaf, Djafar. 1994. Konglomerasi, Taipan dan Koneksi Bisnis. Jakarta: Warta Ekonomi.

Hamna, Dian Muhtadiah. 2018. Konvergensi Media Terhadap Kinerja Jurnalis (Studi Kasus: Fajar TV dan Fajar FM). Jurnal Dakwah Tabligh. Vol. 19 (1): 5883. https://doi.org/10.24252/jdt.v19i1.5911

Karman. 2014. Monopoli Kepemilikan Media \& Lenyapnya Hak Publik. Jurnal Penelitian Teknologi Informasi dan Komunikasi. Vol. 5 (1): 69-84.

Kriyantono, Rahcmat. 200. Tekhnik Praktis Riset Komunikasi. Jakarta: Kencana Prenada Media Group.

Lim, Merlyna. 2011. @crossroads: Democratization E Corporatization of Media in Indonesia. Participatory Media Lab University of Arizona \& Ford Foundation.

Mufid, Muhammad. 2007. Komunikasi dan Regulasi Penyiaran. Jakarta: Kencana Prenada Media Group.

P. Priasmono, dkk. 1994. Konglomerasi Ekonomi Indonesia dalam Rangka Persatuan Bangsa Suatu Tanggung Jawab Sosial. Jakarta: LPS.

Prihartono, Anton Wahyu. 2016. Surat Kabar \& Konvergensi Media (Studi Deskriptif Kualitatif Model Konvergensi Media Pada Solopos). Channel: Jurnal Komunikasi. Vol. 4 (1): 105-116. http://dx.doi.org/10.12928/channel. $\underline{\mathrm{v} 4 \mathrm{i} 1.4210}$

Raharjo, S. 2012. Media Relations di Era Konglomerasi Media. Jurnal Komunikasi $7(1)$.

Sulistiana, Widia. 2017. Industri Media Massa Lokal dalam Tinjauan Manajemen Media Ideal. JIKE 1(1).

Supadiyanto. 2020. Pengantar Jurnalisme Konvergentif (Menjawab Tren Industri Media Digital). Yogyakarta: Pustaka Baru Press.

Syukwansyah, Deden. 2016. Pengembangan Bisnis Joeragan Dengan Menggunakan Pendekatan Prinsip Efektual. Manajemen dan Start-Up Bisnis 1(2).

Zulfiningrum, R. 2014. Spasialisasi dan Praktik Konglomerasi Media Kelompok Kompas Gramedia. Jurnal Aspikom 2(3):140-153. 
78 | Dampak Konglomerasi Media Terhadap Industri Media Massa...

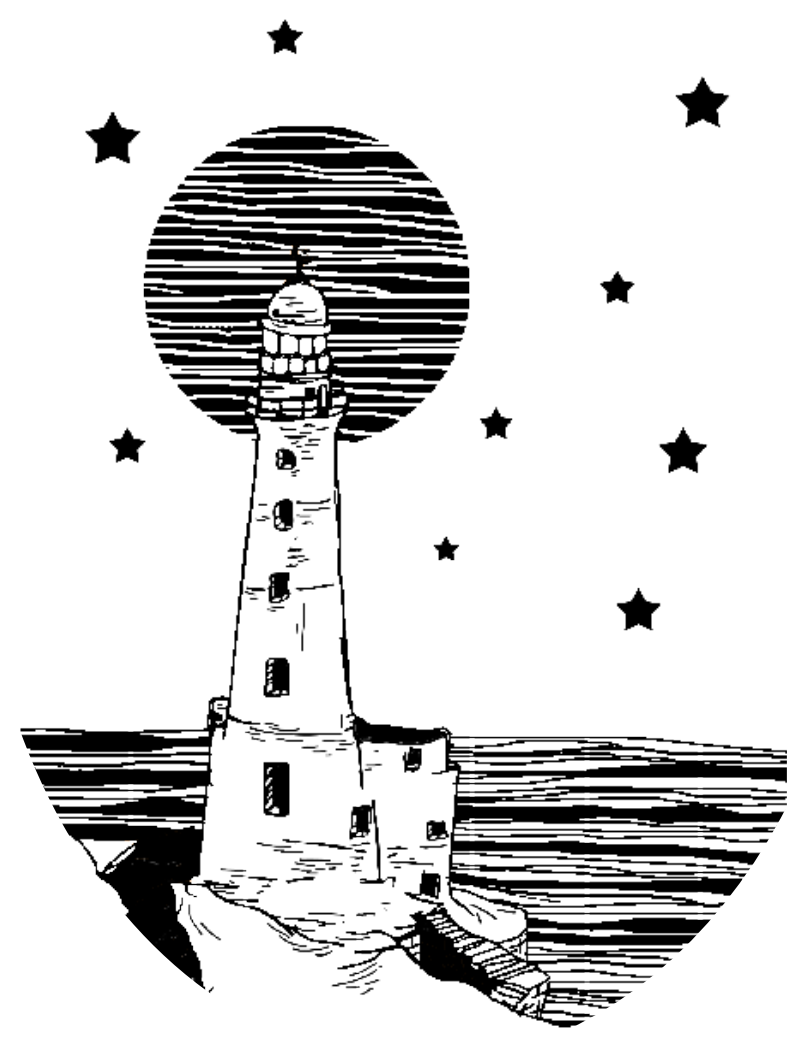

